\title{
The study on decreasing of nitrogen oxides emission carried out on DKVR 10-13 industrial heating boilers
}

\author{
Sylwia Janta-Lipińska ${ }^{1, *}$, and Alexander Shkarovskiy ${ }^{1,2}$ \\ ${ }^{1}$ Koszalin University of Technology, Faculty of Civil Engineering, Environmental and Geodetic \\ Sciences, Sniadeckich 2, 75-452 Koszalin, Poland \\ ${ }^{2}$ Saint Petersburg State University of Architecture and Civil Engineering, 2-nd Krasnoarmeiskaya St. \\ 4, 190005 St. Petersburg, Russia
}

\begin{abstract}
Nitrogen oxides are considered to be much more toxic than, for example, carbon monoxide. For this reason, the Authors developed and implemented a method for decrease of $\mathrm{NO}_{\mathrm{x}}$ emission into the atmosphere from DKVR 10-13 boilers. As an effective method for boilers propose injection of steam into the combustion zone. After series of experimental studies an optimal design of the head for steam injection was developed, according to the proprietary technology. The injector head was kept unchanged while the spraying end caps were modified (Fig. 2). Three levels of possible impact of emissions from boiler on the atmosphere pollution were taken into account during studies. After the analysis, it was assumed that the level of the real maximum emission should be taken as the reference level in relation to which the decrease of NOx emission should be determined. The results obtained by the Authors calculated into mass emission and as objective values of nitrogen oxides concentration calculated into $\alpha=1$ (Figures 3 and 4). Realization of the study plan, assumed by the Authors, allowed to determine the optimal parameters of the $\mathrm{NO}_{\mathrm{x}}$ emission decrease method, assuming the expected $30 \%$ level of emission decrease at a limited consumption of injected.
\end{abstract}

\section{Introduction}

One of the main scientific and technical issues of organic fuel combustion improvement is a necessity to solve complicated and often contradictory tasks aimed at increasing the efficiency of fuel use and decreasing emissions of harmful components of the exhaust gases into the atmosphere [1]. Modern, highly efficient engineering and technical solutions of that issues are most often implemented in large energetic facilities, where any implementation of new technology or equipment change gives a noticeable effect for economy and ecology. Variety of methods for solving energetic and ecological polyoptimisation of fuel combustion results from a huge variability of fire grates and burners [2, 3]. This paper

\footnotetext{
* Corresponding author: sylwia.janta-lipinska@tu.koszalin.pl
} 
presents the results of studies on the decrease of nitrogen oxides $\left(\mathrm{NO}_{\mathrm{x}}\right)$ emission from combustion of fuel in industrial and heating DKVR 10-13 steam boilers [4]. Solutions which have already been implemented in such boilers are: recirculation of part of the exhaust gases, wetting the air supplied to burners and others. Those methods, however, are not widely applied and may cause problems with combustion completeness $[5,6]$. The Authors' goal was to develop their own method of simultaneous decreasing of nitrogen oxides generation and increasing of fuel complete combustion $[7,8]$.

\section{Characteristics of the research object}

The heating boiler plant is located in St. Petersburg at 57 Granitowa St. There are 5 DKVR 10-13 boilers installed there. DKVR 10-13 is a two-drum steam boilers, vertical with the longitudinal location of drums. The nominal capacity of the boiler is 10 tons of steam per hour (with the possibility of a $40 \%$ excess). The maximum overpressure of steam in the drum is 13 bar. The boilers are equipped with two GA-110 burners for gasand-heavy fuel oil (Fig. 1). GA-110 nominal heat output is $5 \mathrm{MW}$ and the nominal gas pressure is $130 \mathrm{dPa}$. The burners are equipped with heavy fuel oil (mazout) sprayers with steam spraying [9]. The fan and exhaust installation of each boiler consists of a VD-10 blow fan and a D-12 exhaust fan. Their parameters are given in table 1.

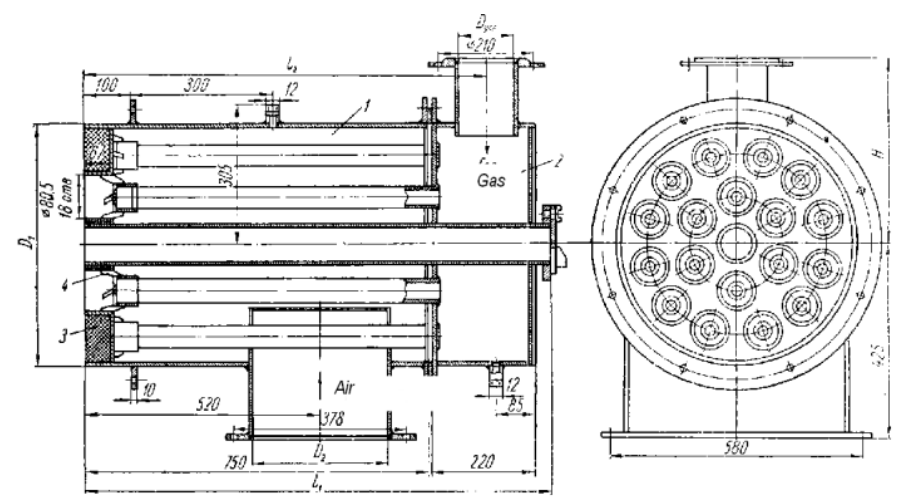

Fig. 1. Diagram of the GA-110 burner.

Table 1. Technical data of a blow and exhaust fans.

\begin{tabular}{|c|c|c|c|c|}
\hline Parameter & Symbol & Unit & VD-10 & D-12 \\
\hline Output & $\mathrm{V}$ & $\mathrm{m}^{3} / \mathrm{h}$ & 15000 & 40000 \\
\hline Pressure & $\mathrm{H}$ & $\mathrm{daPa}$ & 270 & 250 \\
\hline Motor power & $\mathrm{N}$ & $\mathrm{kW}$ & 28 & 40 \\
\hline RPM & $\mathrm{n}$ & $\mathrm{min}^{-1}$ & 980 & 980 \\
\hline
\end{tabular}

Exhaust gases are discharged into the atmosphere by two steel stacks. Their diameter is $1150 \mathrm{~mm}$ and their height is $31 \mathrm{~m}$. Each boiler is equipped with a block economizer of surface $\mathrm{F}=708 \mathrm{~m}^{2}$, which is detachable on the exhaust gas line. 


\section{Variants of nitrogen oxides emission decrease}

The technological methods of decrease of nitrogen oxides emission into the atmosphere include: recirculation of exhaust gases and injection of steam into the combustion zone $[7,8]$.

\subsection{Recirculation of exhaust gases}

This method is used mostly in boilers, where their construction and operation modes of furnaces favours very high $\mathrm{NO}_{\mathrm{x}}$ emissions [10-12]. However, the results of numerous studies show an inevitable increase of the unit fuel consumption caused by the use of recirculation in boilers of such class. Taking into account decrease level of $\mathrm{NO}_{\mathrm{x}}$ emissions, this method allows to obtain $60 \%$ decrease in gas boilers and $40-50 \%$ decrease in mazout boilers [12-14]. Such effect may be explained by the decrease of the maximum combustion temperature and a favourable change in the concentration of reactive substances during dilution by the exhaust gases. Recirculation gases may be introduced into blow-in air, into flame core (when the burners are properly modified) or directly into the furnace through the slotted holes. The first method gives the best results.

The predetermined recirculation level for the DKVR 10-13 boiler was approx. 15\%, which in nominal mode is $\mathrm{V}_{\mathrm{r}}=0.65 \mathrm{~m}^{3} / \mathrm{s}$. Assuming that gas velocity in ducts is $8 \mathrm{~m} / \mathrm{s}$, we can calculate the cross-section area of the recirculation duct $F_{r}=0.081 \mathrm{~m}^{2}$. This corresponds to dimensions of the duct $250 \times 350 \mathrm{~mm}$. Implementation of recirculation in low and medium power boilers is problematic for two reasons: possible limitations related to the efficiency of blow and exhaust fans, as well as stabilization of the optimal recirculation degree exceeds operational possibilities. This is caused by instability and high variability of technological processes, which is characteristic for boilers of such class. That is why method of simplified recirculation method in industrial heating boilers is not widely applied.

\subsection{Injection of steam}

This method causes decrease of formation of nitrogen oxides, benzo(a)pyrene, lowers of the incomplete combustion [3] and emission of soot in boilers, which are not suitable for the application of exhaust gases recirculation or introduction of two-stage combustion. Heterogenity of composition and temperature of the flame along the furnace, favours application of this method.

The preliminary analysis shows the optimum amount of steam injected into the combustion zone is about $1 \%$ of stream of air fed into the combustion $[4,7,8]$. The air volume flow for the boiler in nominal mode is $3.1 \mathrm{~m}^{3} / \mathrm{s}$, which corresponds to the mass flow of $3.66 \mathrm{~kg} / \mathrm{s}$ at $20^{\circ} \mathrm{C}$. Therefore, the steam mass flow is $0.04 \mathrm{~kg} / \mathrm{s}$ or $144 \mathrm{~kg} / \mathrm{h}$. This corresponds to a water-fuel ratio (WPS) of 0.18 [15]. Decrease of the boiler's efficiency should not exceed $0.5 \%$, which may be entirely compensated by optimization of the boiler's operating mode, that is by improvement of combustion completeness and decrease of the excess air coefficient, both due to steam injection. 


\subsection{Selection of method and development of construction characteristics}

Consideration of advantages and disadvantages of two methods discussed above allowed to conclude that the recirculation method in comparison with the injection of steam is characterized by significant material consumption associated with assembly of additional ducts in boiler plant. Decrease of $\mathrm{NO}_{\mathrm{x}}$ emission by the use of recirculation, does no decrease the total toxicity coefficient of the exhaust gases (due to the incomplete combustion). Taking all mentioned above into account, injection of steam into the combustion zone was selected for further development and implementation as a method of decrease of emission of nitrogen oxides in DKVR boilers [4].

After extensive experimental studies, optimal design of the head for steam injection was developed, according to the proprietary technology [16]. The injector head was kept unchanged while the spraying end caps were modified (Fig. 2). Each boiler is characterized by an individual flame shape and separation of substances which react in it. Therefore, this modification should be prepared for individual case of each boiler in order to minimize the amount of injected steam and decrease its impact on the efficiency of boiler. For this purpose, angle of gape of steam streams and diameter of holes are precisely calculated to ensure that steam is supplied to the zones of intensive generation of nitrogen oxides.
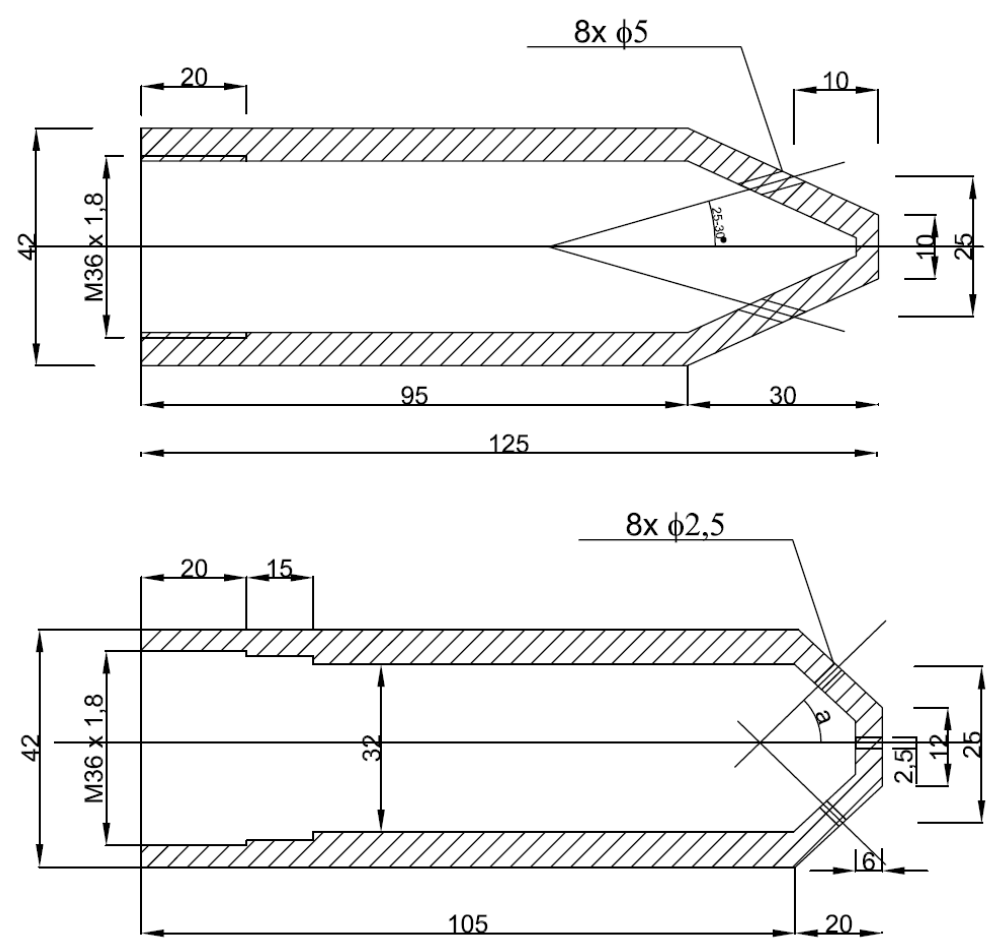

Fig. 2. Diagram of injector end cap (upper - currently used, lower - modified, proposed). 


\section{Experimental studies}

The experimental research program included:

1. Determination of the real level of emissions in the operational technical state of boilers, which is the reference level.

2. Attempt to optimize boiler operation aimed at decreasing $\mathrm{NO}_{\mathrm{x}}$ emission without using additional technical measures.

3. Determination of the best construction parameters of injector heads.

4. Determination of the most favourable, in terms of steam consumption, operating mode which ensures the expected results.

The assumed maximum computational emission of nitrogen oxides emitted to the atmosphere, calculated to $\mathrm{NO}_{2}$ was $0.755 \mathrm{~g} / \mathrm{s}$ [15]. But after analysis, real maximum emission was selected as a more reliable reference level in relation to which the ecological effect should be determined. Steam injection to the combustion zone as a method of decrease of NOx generation was conducted using the mazout injectors, a part of GA type burners. During the observations it was found that the steam cloud is in the required location of the flame core. This confirmed that original assumptions of adopted method are valid. The following parameters were changed during studies, to obtain the optimal results (maximum decrease of $\mathrm{NO}_{\mathrm{x}}$ emission, minimal steam consumption and minimal impact on the boiler's efficiency): method of steam spraying, type and dimensions of injector heads, shape of the steam cloud, place of steam injection to the combustion zone, steam pressure and the ratio of streams fed through various head elements into different zones of flame [17].

Realization of the above mentioned study program allowed to determine the optimal parameters of the $\mathrm{NO}_{\mathrm{x}}$ emission decrease method, assuming the expected $30 \%$ level of emission decrease.

\section{Results of experimental studies}

During analysis of the experimental studies results, four levels of the possible impact of nitrogen oxides emission in exhaust gases on atmosphere were considered:

1. The maximum computational emission level, which for the DKVR 10-13 boiler was $0.755 \mathrm{~g} / \mathrm{s}$.

2. The maximum real level determined experimentally during inventory works, which was $0.797 \mathrm{~g} / \mathrm{s}$.

3. Emission level decreased by $30 \%$ according to initial assumptions, which was $0.558 \mathrm{~g} / \mathrm{s}$.

4. Emission level decreased by $50 \%$ to $0.398 \mathrm{~g} / \mathrm{s}$. Below this level application of the method is no longer justified (in boiler modes of low efficiency).

Data of $\mathrm{NO}_{\mathrm{x}}$ mass emissions and 4 levels mentioned above are presented in Fig. 3. Fig. 3 shows that the real emission in the boiler's basic operating mode exceeds the maximum computational emission level only in modes of exceeded computational efficiency (curve 1). Curve 2 shows the optimal operating mode of $\mathrm{NO}_{\mathrm{x}}$ emission decrease method, developed during studies. It allows to decrease emission by not less than $30 \%$ of the real maximum level with steam consumption not exceeding $1 \%$ of boiler steam capacity. This indicator is two times lower than values given in the literature. 


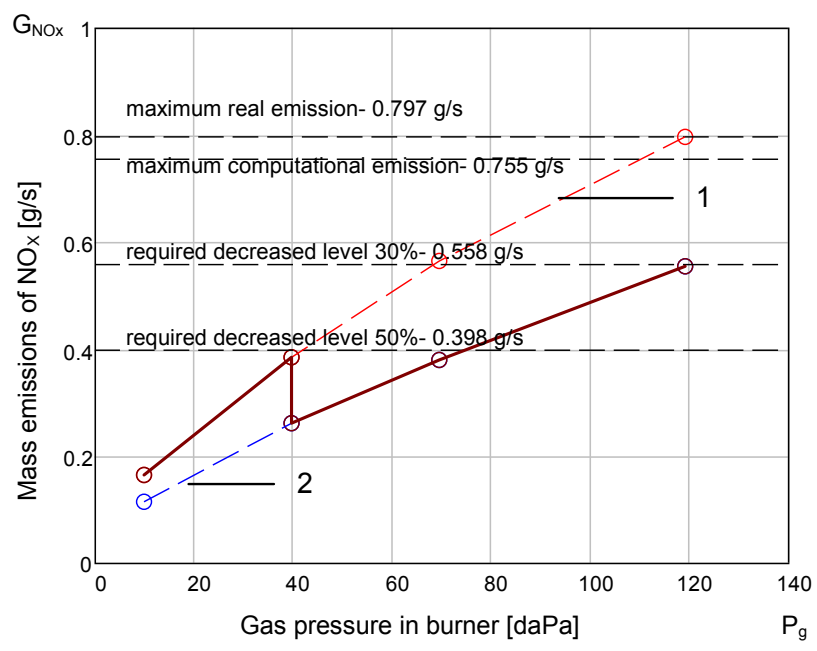

Fig. 3. Mass $\mathrm{NO}_{\mathrm{x}}$ emission from DKVR $10-13$ boiler; 1 - in basic operating mode, 2 - with nitrogen oxides emission decrease method applied. The bold line shows the recommended way of the method application.

The injection of steam at high velocity into precisely determined zones of the flame core highly intensifies the mixing of gas and air streams, and thus also the intra-flame processes. In addition, part of steam dissociates in the high temperature zone into $\mathrm{H}^{+}$and $\mathrm{OH}^{-}$radicals which causes acceleration of combustion processes. It should be noted that increase of concentration of triatomic gases in the furnace space causes increase of blackness degree of this space and thus increase of the heat exchange through screen surfaces by radiation. All mentioned allowed to reduce the amount of air required for full and complete combustion by an average of $15 \%$. Such increase of excess air decreases physical and exhaust heat losses by about $1-1.2 \%$, which completely compensates steam consumption for injection. Therefore, steam consumption for used method of decrease is compensated by increasing efficiency of boiler and thus gross boiler efficiency remains unchanged $[7,8]$.

As a result of analysis of both variants of $\mathrm{NO}_{\mathrm{x}}$ emission limitation (optimization and method of steam injection) a combined method was selected for further implementation. It assumes that when the boiler load exceeds $80 \%$ (gas pressure above $40 \mathrm{dPa}$ ) system of steam injection is active, while at lower loads the boiler works with steam injection disabled, i.e. according to the optimized work card. This method is shown in Fig. 3 as a bold line. Mass emission of substances requires special calculations, therefore Fig. 4 shows objective values of $\mathrm{NO}_{\mathrm{x}}$ concentration. The data was calculated into $\alpha=1$ in order to avoid impact of dilution of exhaust gases on obtained measurement results. 


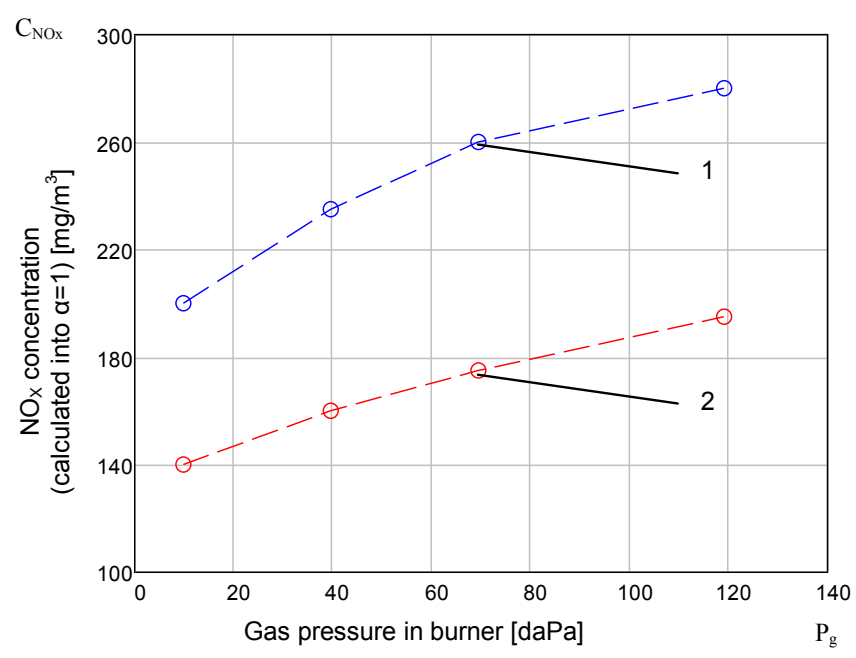

Fig. 4. $\mathrm{NO}_{\mathrm{x}}$ concentration (calculated into $\alpha=1$ ) in exhaust gases form DKVR 10-13 boiler; 1 under real operating conditions; 2 - with enabled nitrogen oxides emission decrease system.

\section{Conclusions}

1. The real emission levels form boilers, which only in nominal load modes are close to or exceed the maximum design values, were determined.

2. The system of nitrogen oxides emission decrease by steam injection with a specific type of spraying device, the method of its assembly and the place and quantity of injected steam, has been developed and implemented in DKVR 10-13 boilers.

3. The optimum mode of operation of the system for nitrogen oxides emission limitation, which allows to achieve the required decrease of emission of at least $30 \%$ at a limited consumption of injected steam (not more than 1\% of boiler steam capacity), has been determined.

4. Intensification of combustion processes caused by steam allows to increase the efficiency of boilers by about $1 \%$, which fully compensates steam consumption for injection.

\section{References}

1. D. Fijałkowska, L. Styszko, Rocz. Ochr. Sr. 13, 875-890 (2011)

2. A. Szkarowski, Podwyższenie efektywności ochrony atmosfery przy spalaniu gazowego i ciekłego paliwa. Autoreferat rozprawy habilitacyjnej. Sankt-Petersburg (1997)

3. A. Szkarowski, S. Janta-Lipińska, Rocz. Ochr. Sr. 15, 981-995 (2013)

4. A. Szkarowski, S. Janta-Lipińska, R. Gawin, Rocz. Ochr. Sr. 18, 565-578 (2016)

5. A. Szkarowski, Rocz. Ochr. Sr. 5, 67-78 (2003)

6. A. Szkarowski, S. Janta-Lipińska, Rocz. Ochr. Sr. 13, 511-524 (2011)

7. A. Szkarowski, Rocz. Ochr. Sr. 3, 53-73 (2001)

8. A. Szkarowski, Rocz. Ochr. Sr. 4, 365-378 (2002)

9. A. Pavlenko, A. Szkarowski, S. Janta-Lipińska, Rocz. Ochr. Sr. 16, 376-385 (2014)

10. J. Szyszlak-Bargłowicz, G. Zając, T. Słowik, Rocz. Ochr. Sr. 19, 715-730 (2017) 
11. P.W. Roslakow, Energetyka Cieplna 1, 1, 37-41 (1986)

12. A. Szkarowski, S. Janta- Lipińska, Rocz. Ochr. Sr. 11, 241-255 (2009a)

13. A. Szkarowski, S. Janta-Lipińska, Rocz. Ochr. Sr. 17, 576-584 (2015)

14. Z. Kalicka, W. Jerzak, E. Kawecka-Cebula, Arch. Environ. Prot. 39, 4, 93-103 (2013)

15. Сборник методик по расчету выбросов в атмосферу загрязняющихвеществ различными производствами Л. Гидрометеоиздат. Госкомгидромет (1986)

16. A.A. Jemieljanow, Opracowanie urządzeń wtryskujących dla zdtawienia tlenków azotu przy spalaniu gazu i mazutu w paleniskach kottów. Autoreferat rozprawy doktorskiej. Sankt-Petersburg (1992)

17. Н. Кузнецова и др. Тепловой расчет котельных агрегатов: Норматив. метод. М.: Энергия (1973) 